\title{
Circulating tumor cells in clinical research and monitoring patients with colorectal cancer
}

\author{
Claudia Burz ${ }^{1,2}$, Vlad-Vasile Pop ${ }^{1}$, Rares Buiga ${ }^{2}$, Sur Daniel ${ }^{1,2}$, Gabriel Samasca ${ }^{1,3}$, \\ Cornel Aldea ${ }^{3}$ and Iulia Lupan ${ }^{4,5}$ \\ ${ }^{1}$ Iuliu Hatieganu University of Medicine and Pharmacy, Department Of Immunology and Allergology, Cluj-Napoca, Romania \\ ${ }^{2}$ Ion Chiricuta Institute of Oncology, Cluj-Napoca, Romania \\ ${ }^{3}$ Emergency Hospital for Children, Cluj-Napoca, Romania \\ ${ }^{4}$ Babeș-Bolyai University, Department of Molecular Biology and Biotehnology, Cluj-Napoca, Romania \\ ${ }^{5}$ Institute of Interdisciplinary Research in Bio-Nano-Sciences, Cluj-Napoca, Romania \\ Correspondence to: Vlad-Vasile Pop, email: popvlad92@gmail.com \\ Keywords: colorectal cancer; circulating tumor cells; metastasis; prognostic factor; survival \\ Received: April 27, $2017 \quad$ Accepted: April 24, $2018 \quad$ Published: May 11, 2018
}

Copyright: Burz et al. This is an open-access article distributed under the terms of the Creative Commons Attribution License 3.0 (CC BY 3.0 ), which permits unrestricted use, distribution, and reproduction in any medium, provided the original author and source are credited.

\section{ABSTRACT}

Colorectal cancer remains a frequent disease to which screening and target therapy exist, but despite this is still marked by a high mortality rate. Even though radical surgery may be performed in many cases, patients relapse with metastatic disease. Circulating tumor cells were incriminated for tumor recurrence, that's why vigorous research started on their field. Owning prognostic and predictive value, it was revealed their usefulness in disease monitoring. Moreover, they may serve as liquid biopsies for genetic tests in cases where tissue biopsy is contraindicated or cannot be performed. In spite of these advantages, they were not included in clinical guidelines, despite CellSearch and many other detection methods were developed to ease the identification of circulating tumor cells. This review highlights the implication of circulating tumor cells in metastasis cascade, intrinsic tumor cells mechanisms and correlations with clinical parameters along with their utility for medical practice and detection techniques.

\section{INTRODUCTION}

Colorectal cancer (CRC) is the third most frequent cancer in men and second in women worldwide, marked by 694000 deaths/year. In Europe it causes among all types of cancers 215000 deaths/year [1]. More importantly, one in four patients at the diagnosis presents distant metastases and half of patients which undergo curative surgery will develop metastases. With a 5-year survival rate of $60 \%$, $\mathrm{CRC}$ remains a major health problem worldwide and in areas considered in past at low risk. It is considered as a result of "westernisation", by coping vices like heavy alcohol use, smoking, bad eating habits by consuming large amounts of red meat and sedentariness [1,2].

Early CRC detection represents not only a favourable disease prognostic, but also a mark of an efficient treatment. In order to fulfil this condition, tumor screening is imperative. Faecal occult blood test despite being highly cost-effective, it has high false positives results [3]. Endoscopy, represented by flexible sigmoidoscopy and colonoscopy, along with double contrast barium enemas are thoroughly invasive. Modern imaging techniques such as computed tomography (CT) and magnetic resonance imaging (MRI) are highly expensive and more importantly, their application as screening methods is limited by radiation exposure. As a consequence of these issues, for early CRC diagnosis a non-invasive, valid and reasonably economical method is required [4].

Treatment of CRC varies with the disease stage. The curable one in early CRC remains surgery; however, $50 \%$ of patients develop metastases [1]. In metastatic CRC (mCRC) several therapeutic options are available, such as vascular endothelial growth factor (VEGF)-targeted therapy - Bevacizumab, anti-epidermal growth factor receptor targeted therapy - Cetuximab, Panitumumab), often associated with chemotherapy - the most active drugs being 5 Fluoro-uracil, Oxaliplatin, Irinotecan and 
Capecitabine. Despite the treatment progress in mCRC, the patient's prognosis is still low, with a median survival between five and 19 months [5]. Such being the case, disease monitoring and surveillance must be performed by using imaging techniques and cancer specific markers. Although improvements have been made in this field, many of these biomarkers are not used in clinical practice due to their elaborative detection or cost [6]. A series of them can be listed, from carcinoembryonic antigen (CEA), cancer antigen 19-9 (CA 19-9), microsatellite instability (MSI), V-Ki-ras2 Kirsten rat sarcoma viral oncogene homolog (KRAS), tumor protein p53 to circulating DNA, RNA and circulating tumor cells (CTCs) [7]. The last have attracted a great deal of attention to scientific research due to their roles in metastasis and possibility of being liquid biopsies as an alternative for tissue biopsies for genetic tests. Besides, they proved their importance in patients derived xenografts (PDXs) models for future drug studies, therapy monitoring and clinical parameters like overall survival (OS), progression free survival (PFS) in mCRC patients $[6,8-13]$. In this context, this review endeavours to emphasize the roles, importance and detection methods of CTCs in early stage and mCRC.

\section{BIOLOGY OF CTCs}

At early stages, from the primary tumor after epithelial-to-mesenchymal transition of primary cancer cells, CTCs begin to flow into blood stream at a rate of roughly $10^{6}$ cells per tumor gram $[6,14,15]$. The idea of CTCs was first implemented by Asworth in 1869. Later in 1955, Engell described the cells found in peripheral circulatory system and in the tumor blood drainage area of different types of cancer patients $[4,16]$. While cells present in the blood flow are named CTCs, the ones that reach and implant in the bone marrow are called disseminated tumor cells (DTCs) [8, 10]. At this level, recent studies implemented that in certain types of cancer, including gastrointestinal malignancies, different progenitors of bone marrow stem cells represent a major key in cancer development and progression [17-19]. However, it remains unclear if these cells represent a section of the CTCs. Future research in this field must be conducted to solve the dilemma.

Adhering through cell adhesion molecules to the vascular endothelium, CTCs stand at the foundation of the biologic mechanism of metastasis in various types of cancers $[20,21]$. This statement is justified by preclinical studies conducted on murine models, where human cancer cells were implanted in renal subcapsular regions and then CTCs along with metastases were detected and characterized [22].

The process of metastasis consists of two phases: pre-colonization and colonization. The pre-colonization phase which takes part in minutes to hours on a timescale, involves intravasation of cancer cells within vasculature of the tumor, after the local invasion of them of the primary tumor. Afterwards, as single cells or platelet coated clusters, they infiltrate the circulatory system through which they pass in target organs, arresting in capillaries to start colonization. Being a laborious process, which transpires in years, colonization commences with extravasation of cancer cells, which set up resistance to host-tissue immunity in supportive niches. Subsequently, to carry out a long-standing survival, the cells as micrometastases or single units adopt a latent state. When they end latency, the process of metastasis continues with the overtaking of the target organs (Figure 1A-1B) [23].

Homing of CTCs by the viscera, as for example the liver, is not a chaotic mechanism, but in fact a controlled one, under the influence of certain natural ligands present in its vessels. The specific pathway seems to be coordinated by angiopoietin-like 6 protein. This ligand binds to E-cadherin and $\alpha$ [6] integrin found on the CTCs surface and thus enhances colonization of the liver [24]. Regarding the pattern of haematogenous CTCs dissemination, it was observed that the number of cells was higher in mesenteric venous blood compartments than in central one [25].

It is already known that the malignant progression requires avoidance and repression of the immune system [26]. Natural killer (NK) and cytotoxic T cells are responsible with immune surveillance over the microenvironment. Each organ consists in different specific levels of immune cells i.e. the liver, which is rich in NK. In mice, depriving the liver of pro-apoptotic NK cell-derived tumor necrosis factor-related apoptosisinducing ligand, the process of metastasis was enhanced [23]. Reported scientific data suggests that CTCs influence innate immunity in metastatic breast, prostatic and CRC. By determining NK cytotoxicity towards cancer cells in these patients, it was observed a direct relation between CTCs and immune cells. Thus, a down regulation of the cytotoxic activity of NK was revealed in patients with high CTCs levels in peripheral blood. Moreover, this statement is supported by the decreased levels of toll-like receptors 2 and 4 that play a key role in immune response. By manipulating the immune pathways, down regulation of Ki-67, c-myc, $\beta$-catenin and over expression of CD47, CTCs seem to enhance the metastatic cascade and survive in the blood stream in a state of dormancy [27]. Their genetic profile appears to be altered, as their molecular characteristics were more concordant to metastases, than to the primary tumor $[28,29]$.

Immune system also plays an important role in cancer patients with severe and complicated postoperative infections such as sepsis, pneumonia, peritonitis, by enhancing metastasis and increasing the risk of death from the process. Neutrophils, which act in infections as first line of defence, are incriminated as a supporter for the metastasis progression through neutrophil extracellular traps (NETs). Formed as a response to infections, NETs 
consist in extruded DNA and antimicrobial proteins that have anti-bacterial, fungal and protozoal effects. However, despite the positive immune role, experimental data conducted on murine hepatic tissue revealed that CTCs are trapped in NETs and as a result, metastatic lesions increased rapidly [30]. Other cells, such as tumorassociated macrophages (TAMs) exceed their role in immune surveillance and become effectors for metastasis by producing growth factors, cytokines, chemokines as well as hormones and metabolites that hold tumor supporting effects. TAMs are derived to solid tumors as a response to chemoattractants, VEGF and endothelin-2 (ET-2), especially in hypoxic regions of growing tumors. Attracted by these factors, they interact with CTCs which inculcate TAMs to nurture tumor invasion, CTCs intravasation and their survival in the foreign microenvironment [31, 32].

Consequently, taking all these biologic mechanisms into consideration, slightly new therapeutic approaches must be taken into consideration in patients with higher number of CTCs [33].

\section{DETECTION AND USEFULNESS OF CTCS}

Despite the large amount of CTCs released daily, they are found in low concentration in the peripheral blood. This dilemma is caused by platelets cloaks or coagulation factors that surround the CTCs, shielding them from the immune surveillance. As a result, a fraction of cells may remain undetectable [34]. Subsequently, their detection represents a challenge, mostly for developing a method of high sensibility and sensitivity [4]. So far, there were described many methods of detection such as immunocytochemistry, flow cytometry, optical fiber array scanning, reverse transcriptase polymerase chain reaction (RT-PCR), immunomagnetic separation, microchips, and others $[16,35]$. From those, only the CellSearch System (Veridex LLC, Raritan, NJ) was approved by US Food and Drug Administration (FDA) in 2004 for breast, prostate and CRC, but it was not included by American Society of Clinical Oncology in clinical practice $[4,16]$. With limited information on CTCs usage guidelines, didn't recommend their use only in certain situations, despite being a valid prognostic biomarker. In this matter imperative further studies must be conducted to clarify their place in clinical practice [36].

Concerning their identification, CTCs detection techniques can be realised without cell enrichment or through enrichment strategies depending on their physical or biological properties. Without enrichment, in clinical practice or on cell cultures, several methods were reported such as fiber-optic array scanning technology, density based cell mechanism combined with digital scanning microscope (AccuCyte-CyteFinder system) or Epic Platform. Enrichment based on physical properties methods isolate CTCs depending on their size, deformability, density and electric charges. In research were used many of them, like flexible microspring array, CelleSieve microfilter and the isolation by size of the epithelial tumor cells [37, 38]. Based on their biological properties, CTCs enrichment strategies are divided in two methods. Positive enrichment techniques capture CTCs and release normal cells, i.e. Epithelial cells adhesion molecule (EpCAM) used in CellSearch, immunomagnetic beads coated with antibodies like cytokeratin 20 (CK20). The negative enrichment, with an opposite mechanism of the first one, uses the negative marker CD45 or other CDs for detection $[15,38,39]$.
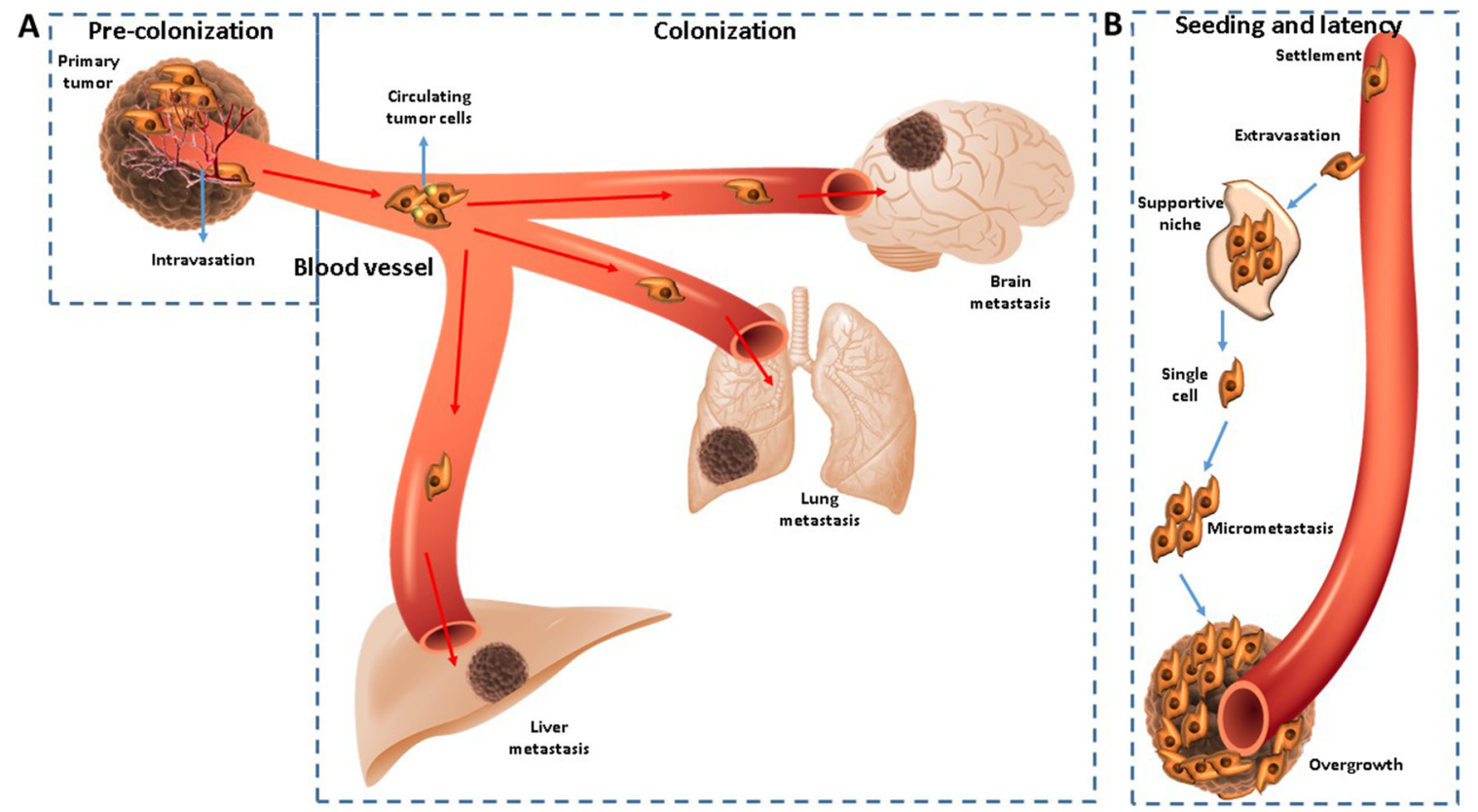

Figure 1: (A-B) CTCs are disseminated from primary tumor sites and a bridge for relapse or metastasis. 
However, some changes in the CTCs molecular biology interfere in the detection process. It was revealed using in vitro evidence, that in mCRC patients, CellSearch may be prevented in detection of CTCs by the Bevacizumab therapy. Its sensibility seems to decrease after long exposure of cells to the VEGF-antibody, due to the low expression of EpCAM $40 \mathrm{kDa}$ isoform and increase expression of the isoform EpCAM 42kDa [40].

Often, for a more exact detection, two or more methods were combined for a more specific counting. CellSearch and AdnaTest which uses an RT-PCR method to detect specific cells from the EpCAM enriched fraction, was used in $\mathrm{mCRC}$ and was found superior to using one single method [41].

Besides, new technologies are imagined and used in vitro or in vivo in different types of cancers. In the last fifteen years, several methods were used for CTCs detection and analysis [42]. Many scientists tried to invent and optimize their method to add it in clinical protocols (Table 1).

Despite their variety, it remains imperative to select or generate a sensible and specific detection method. Afterwards, it must be verified on a suitable number of patients to prove CTCs importance and clinical utility as markers for medical practice.

Besides their molecular characteristics, the usefulness of peripheral blood CTCs in clinical implication was seen to have a great importance in early stage and metastatic cancer. In non-metastatic CRC patients, CTCs detected preoperative represent a valid prognostic factor for cancer progression and survival [64]. In patients that underwent surgical resection of the primary tumor, CTCs revealed an increased risk of postoperative metastasis [65]. Their persistent presence after curative resection was associated with poor prognosis and relapse free survival (RFS) [66].

In $\mathrm{mCRC}$ data from relevant studies unveiled that they are predictive markers for chemotherapy through discerning the potential metastases prematurely, choosing patients resistant to chemotherapy and ascertaining clinical outcomes. Being a prognostic marker, in particular cases of mCRC, where levels of CEA and other markers were found not measurable, CTCs fulfilled a better disease monitoring [6]. More important, CTCs high levels were associated with clinical outcome parameters like worse progression free survival (PFS) and overall survival (OS) in CRC patients [6, 66-68]. As a further matter, higher level of CTCs was correlated with tumor relapse due to their conversion in cancer stem cells that start recurrence [69].

Epithelial to mesenchymal transition (EMT) is a process which CTCs gain to enable metastasis. In mCRC patients, by examining the CTCs-microRNA (mRNA) expression of EMT different transcripts implicated in cell migration, it was observed a correlation with OS and PFS [70]. Other studies conducted on healthy donors and mCRC patients, revealed that mRNA molecular characterization of CTCs is possible in order to attempt further individualized treatment [71].

Furthermore, CTCs were revealed to diagnosis liver metastases (LM). Using flow cytometry to detect cellular subpopulations of CTCs in MCRC with LM and non-metastatic CRC, it was observed that CD133, CD54 and CD44 were higher in MCRC-LM patients, proving the strong association between these cellular subpopulations and LM. Untimely and right LM diagnosis allows the option of performing a liver-targeted therapy to improve survival. By merging modern abdominal imaging with CEA, CA 19-9 and CD differentiation of CTCs, it was unveiled an increased sensitivity and specificity in detection the LM. Thus, CTCs may play a role in this matter as a predictive and auxiliary diagnosis marker [72].

To strengthen the argument of auxiliary markers, there were conducted a series of studies on chemotherapy treated mCRC. Each study detected patient's CTCs at different points in their evolution and concluded the correlations between CTCs and imaging response to therapy, PFS and OS (Table 2).

However, there are a series of discordances between patient's treatments, time of blood samples collection, CTCs levels reference value, detection methods and imaging methods used for disease staging. Even if it's clear that CTCs reflects therapy response, the differences must be settled in order to strengthen their importance as useful markers for clinical practice.

Consequently, in early stage CRC CTCs detection is correlated with cancer progression and poor prognosis, whereas in $\mathrm{mCRC}$ the biomarker high levels indicate disease progression, along with on overall poor outcome [64].

Besides their roles mentioned until this point, their implication as auxiliary markers represents more than meets the eye. CTCs were proposed to be used as liquid biopsies as an alternative for tissue biopsies for precision medicine or in PDXs models because of their effortless collection and possibility of tracking disease evolution at any step $[9,13,79]$.

Similar to CTCs, circulating cell-free DNA (cfDNA) has attracted a great deal of attention in biomedical research. Detected in the cell-free portion of whole blood, cfDNA was first reported in 1948 by Mandel and Metais and since, it remains a promising area of research in many medical disciplines. Exercise, trauma, myocardial infarction, stroke, end-stage kidney failure represent some of the situations that increase the levels cfDNA. In cancer patients, a minor portion of cfDNA is represented by circulating tumor DNA (ctDNA) from tumor shedding. In order to guide targeted therapy, molecular analysis of tumor tissue is imperative to detect the gene mutations. This process is sometimes hampered by heterogeneity of the primary tumor and metastases [80]. Moreover, the biopsy itself does not lack of limitations such as clinical 
Table 1: Different methods for CTCs detection and analysis

\begin{tabular}{|c|c|}
\hline Detection method & Reference \\
\hline Biomimetic lipid coated microfluids & [43] \\
\hline Celsee device microfluidic chip-based & [44] \\
\hline Micromagnet-integrated microfluidic screening system & {$[45]$} \\
\hline Inkjet-printed microscale magnetic structure on glass slides & [46] \\
\hline Electrical detection method using graphene nanoplates & [47] \\
\hline Immunomagnetic negative enrichment and fluorescence-activated cell sorting & [48] \\
\hline Size-based isolation with a novel filter device (FMSA) & {$[38,49]$} \\
\hline Nanostructured polystyrene well plates & {$[50]$} \\
\hline Filter separation and 5-aminolevulinic acid (5-ALA) & {$[51]$} \\
\hline Multiplex-PCR & {$[38,52]$} \\
\hline Micro-Raman microscopic & {$[53]$} \\
\hline Biocompatible $\mathrm{TiO} 2$ nanoparticle-based cell immunoassay & {$[54]$} \\
\hline DEPArray dielectrophoresis-based platform & {$[38,55]$} \\
\hline Microfluidic bead-based multienzyme-nanoparticle amplification & {$[56]$} \\
\hline Hybrid polydimethylsiloxane microfluidic device & {$[57]$} \\
\hline Quantum-dot-labelled magnetic immunoassay & {$[58]$} \\
\hline Electrospun $\mathrm{TiO} 2$ nanofiber-based cell capture assay & {$[59]$} \\
\hline ScreenCell Cyto & {$[60]$} \\
\hline Epispot assay & {$[38,61]$} \\
\hline CELLection Epithelial Enrich system & {$[62]$} \\
\hline High-throughput microsampling unit (HTMSU) & {$[63]$} \\
\hline
\end{tabular}

complications, costs and invasiveness. Taking these arguments into account, ctDNA released from necrosis of cancer cells represents an alternative to the tissue sampling because it can be collected at any time to observe tumor dynamics and mutations, amplifications, rearrangements. Due to an about 2 hour's half time ctDNA enables a better evaluation of tumor dynamics over imaging techniques or conventional biomarkers [81]. Moreover, it can bring essential information about tumor burden, minimal residual disease, the mechanisms of molecular drug resistance and heterogeneity, as well as disease monitoring [81-85].

Both of the biomarkers, CTCs and ctDNA, reflect tumor spatial and temporal heterogeneity, evolution and mutations. In addition, they represent non invasive biopsy methods with a high specificity. Despite this beneficial values, each of these liquid biopsies present a series of limitations and strengths. Regarding the phenotype, genotype, cell cultures and PDXs models of tumor, CTCs represents the most suitable biomarker. From the opposed point of view, ctDNA proves its utility in monitoring the treatment response and relapse [38]. Thus, both are interdependent as liquid biopsies, but present a series of others drawbacks and advantages that define CTCs and ctDNA suitable in different directions (Table 3) [80].
However, overall mutations detected in CTCs and ctDNA like KRAS, BRAF and PIK3CA were virtually in concordance [28]. In clinical practice, KRAS was revealed to have major implication in CRC patients. Its mutation itself is a negative criterion for treatment with targeted anti-EGFR monoclonal antibodies like Cetuximab or Panitimumab. To set up the targeted treatment, KRAS mutation must be assessed from tumor tissue. Due to the difficulty of obtaining an appropriate sample for KRAS genotyping, other alternatives were taken into consideration, like molecular characterization of CTCs. Specific methods, as droplet digital PCR or performing KRAS kits by quantitative PCR, nested Allele-Specific Blocker PCR or wild-type blocking PCR, revealed that is possible to assess KRAS mutation in CTCs from peripheral blood [86-89]. The minimal invasive method could be implemented in clinical practice because of the insight information obtained.

In addition, a stronger prognosis indicator of CTCs was seen through the analysis of programmed deathligand (PD-L1) in CRC patients undergoing treatment. Its expression was quantified at cells membrane, cytoplasm and nucleus. From those, the nucleus high expression was correlated with shorter patient's survival durations [90]. Another recent marker for CTCs is represented by 
Table 2: Comparison between different studies on CTCs levels and imaging response to therapy, PFS and OS

\begin{tabular}{|c|c|c|c|c|c|c|c|c|c|}
\hline $\begin{array}{l}\text { Reference \& } \\
\text { No. patients }\end{array}$ & Chemotherapy & CTCs evaluation & \multicolumn{5}{|c|}{ Response to Imaging and CTCs levels } & PFS & OS \\
\hline \multirow{4}{*}{$\begin{array}{l}\text { Cohen SJ. } \\
430 \mathrm{P} \\
{[73]}\end{array}$} & \multirow{4}{*}{ Heterogeneous } & \multirow{4}{*}{ CellSearch System } & \multirow{2}{*}{$\begin{array}{c}\text { RECIST } \\
3-5 \text { weeks }\end{array}$} & \multicolumn{2}{|c|}{$<3$} & \multicolumn{2}{|c|}{$>3$} & \multirow{4}{*}{$\begin{array}{c}7.2 \mathrm{M} \\
(95 \% \mathrm{CI}, 6.7-7.9 \mathrm{M})\end{array}$} & \multirow{4}{*}{$\begin{array}{c}15.5 \mathrm{M} \\
(95 \% \mathrm{CI}, 14.0-18.4 \mathrm{M})\end{array}$} \\
\hline & & & & No. & $\%$ & No. & $\%$ & & \\
\hline & & & $\mathrm{RR}(\mathrm{SD}, \mathrm{PR}, \mathrm{CR})$ & 228 & 93 & 18 & 7 & & \\
\hline & & & PD & 54 & 73 & 20 & 27 & & \\
\hline \multirow{5}{*}{$\begin{array}{l}\text { Tol J. } \\
467 \mathrm{P} \\
{[74]}\end{array}$} & \multirow{5}{*}{$\begin{array}{c}\text { XELOX } \\
+ \text { Bevacizumab } \\
+/- \text { Cetuximab }\end{array}$} & \multirow{5}{*}{ CellSearch System } & RECIST & \multicolumn{2}{|c|}{ High } & \multicolumn{2}{|c|}{ Low } & \multirow{5}{*}{$\begin{array}{c}10.0 \mathrm{M} \\
(95 \% \mathrm{CI}, 8.8-11.2 \mathrm{M})-\text { low } \\
3.9 \mathrm{M} \\
(95 \% \mathrm{CI}, 1.7-5.4 \mathrm{M})-\text { high }\end{array}$} & \multirow{5}{*}{$\begin{array}{c}20.0 \mathrm{M} \\
(95 \% \mathrm{CI}, 17.8-21.4 \mathrm{M})-\text { low } \\
6.3 \mathrm{M} \\
(95 \% \mathrm{CI}, 3.3-10.5 \mathrm{M})-\text { high }\end{array}$} \\
\hline & & & $1-2$ weeks & No. & $\%$ & No. & $\%$ & & \\
\hline & & & Response & 2 & 11 & 115 & 40 & & \\
\hline & & & SD & 12 & 67 & 158 & 55 & & \\
\hline & & & PD & 4 & 22 & 16 & 5 & & \\
\hline \multirow{4}{*}{$\begin{array}{l}\text { Matsusaka S. } \\
61 \mathrm{P} \\
{[75]}\end{array}$} & \multirow{4}{*}{$\begin{array}{c}\text { FOLFOX4 } \\
+/- \text { Bevacizumab }\end{array}$} & \multirow{4}{*}{ CellSearch System } & \multirow{2}{*}{$\begin{array}{c}\text { RECIST } \\
\text { 8-12 weeks }\end{array}$} & \multicolumn{2}{|c|}{$<3$} & \multicolumn{2}{|c|}{$>3$} & \multirow{4}{*}{$\begin{array}{c}1.9 \mathrm{M} \\
(95 \% \mathrm{CI}, 0.5-3.3 \mathrm{M})>3 \\
9.1 \mathrm{M} \\
(95 \% \mathrm{CI}, 7.6-10.7 \mathrm{M})<3\end{array}$} & \multirow{4}{*}{$\begin{array}{c}4.1 \mathrm{M} \\
(95 \% \mathrm{CI}, 0-11.7 \mathrm{M})>3 \\
29.1 \mathrm{M} \\
(95 \% \mathrm{CI}, 20.3-38.0 \mathrm{M})<3\end{array}$} \\
\hline & & & & \multicolumn{2}{|c|}{ No. } & \multicolumn{2}{|c|}{ No. } & & \\
\hline & & & $\mathrm{RR}(\mathrm{SD}, \mathrm{PR}, \mathrm{CR})$ & \multicolumn{2}{|c|}{52} & \multicolumn{2}{|c|}{1} & & \\
\hline & & & PD & \multicolumn{2}{|c|}{4} & \multicolumn{2}{|c|}{3} & & \\
\hline Sastre I & & & & & & $>$ & & $10.8 \mathrm{M}$ & $25 \mathrm{M}$ \\
\hline $180 \mathrm{P}$ & $\begin{array}{c}\text { XELOX } \\
+ \text { Bevacizumab }\end{array}$ & CellSearch System & $\begin{array}{c}\text { RECIST } \\
8-12 \text { weeks }\end{array}$ & & & 0 & & $\begin{array}{c}(95 \% \mathrm{CI}, 9.7-12.5 \mathrm{M})<3 \\
7.5 \mathrm{M}\end{array}$ & $\begin{array}{c}(95 \% \mathrm{CI}, 20.0-28.3)<3 \\
16.1 \mathrm{M}\end{array}$ \\
\hline & & & & & & 26 & & $(95 \% \mathrm{CI}, 4.0-9.9 \mathrm{M})>3$ & $(95 \% \mathrm{CI}, 9.2-26.0 \mathrm{M})>3$ \\
\hline $\begin{array}{c}\text { Alburqueque } \\
\text { A. } \\
33 \mathrm{P} \\
{[77]}\end{array}$ & Heterogeneous & $\begin{array}{c}\text { Immunomagnetic } \\
\text { enrichment with BM7 } \\
\text { and VU1D9 antibodies }\end{array}$ & & $\mathrm{n} / \mathrm{a}$ & & & & $\begin{array}{c}181 \text { days } \\
(95 \% \text { CI, 146.9-215.1 - } \\
\text { positive CTCs }) \\
329.0 \text { days } \\
(95 \% \text { CI, } 299.6-358.4)-\text { no } \\
\text { CTCs }\end{array}$ & $\mathrm{n} / \mathrm{a}$ \\
\hline & & & & & & $\mathrm{Lc}$ & & $12.1 \mathrm{M}$ & $23.6 \mathrm{M}$ \\
\hline $\begin{array}{c}\text { Barbazan J. } \\
50 \mathrm{P}\end{array}$ & Heterogeneous & $\begin{array}{l}\text { Multimarker CTCs } \\
\text { detection panel }\end{array}$ & $\begin{array}{l}\text { RECISI } \\
4-W\end{array}$ & No. & $\%$ & No. & $\%$ & $\begin{array}{c}(95 \% \mathrm{CI}, 9.7-14.4)-\text { low } \\
7.3 \mathrm{M}\end{array}$ & $\begin{array}{c}(95 \% \mathrm{CI}, 19,9-27,3)-\text { low } \\
12.4 \mathrm{M}\end{array}$ \\
\hline & & & & 38 & 76 & 12 & 24 & $(95 \%$ CI, 4.4-10.2) - high & $(95 \%$ CI, 7,3-17,6) - high \\
\hline
\end{tabular}

Abbreviations: CR, Complete Response CT, computed tomography; CTCs, circulating tumour cells; M, Months; No., number of; OS, overall survival; P, patients; PD Progressive Disease, PFS, progression free survival; PR, Partial Response, RECIST, Response Evaluation Criteria in Solid Tumours; RR, Response Rate; SD, Stable Disease; W, weeks.

\section{Table 3: Advantages and disadvantages of ctDNA and CTC $[38,80]$}

\begin{tabular}{lll}
\hline Advantages & CTC & ctDNA \\
\hline & -Appraise expression of proteins & -Increased genome amount per unit volume which is more \\
& -Ex vivo functional studies & sensitive \\
& -In vitro analyses for evaluation of & -Monitoring disease burden \\
& treatment sensitivity & -Monitoring therapy response and relapse by gathering molecular \\
& -Useful for optimizing therapy & information \\
& selection by DNA, RNA and & -Possibility to elucidate mechanisms of drug-resistance \\
& proteins analysis of cells & \\
& -Early cancer detection & \\
& -Establishing carcinoma origin & \\
Disadvantages & -False-positive results by detecting & -Without expression of proteins \\
& benign circulating epithelial cells & -Impossibility to assess functional studies \\
& in benign inflammatory disease & -Limited molecular profiling \\
& (Crohn disease) & -False-positive results of insignificant molecular mutations due \\
& -Heterogeneity of the population & to method high sensitivity \\
& of CTC & -variable levels of ctDNA in persons \\
& & -In early cancer stages it may be hard to detect
\end{tabular}


Plastin-3 (PLS3) encoded by a gene on a chromosome $\mathrm{Xq} 23$. With a role in EMT induction and invasiveness, PLS3 protein high expression was correlated with poor prognosis of patients with CRC and with a high rate of metastasis [91].

Altogether, the relevance of CTC determination relies in the fact that they represent prognostic and predictive markers for CRC patient. For their role, significance and correlations with clinical outcome, CTCs tend to make the transition from scientific research to clinical guidelines implementation.

\section{CONCLUSIONS}

CTCs remain a subject of major interest for scientific research by standing at the base of metastasis cascade. Moreover, as revealed by many studies, they could represent early prognostic and predictive markers in early and $\mathrm{mCRC}$, revealing crucial information on disease monitoring. In addition, CTCs might serve as non invasive liquid biopsies to test different genetic mutations, like VEGF, KRAS, allowing initiation with targeted therapy such as Bevacizumab, Cetuximab or Panitumumab. The shortage of consensus, due to many differences in detection methods, time of detection and reference value recognize a limited use of CTCs in CRC management.

\section{Author contributions}

All authors contributed equally to this work.

\section{ACKNOWLEDGMENTS AND FUNDING}

This work was supported by "Iuliu Hatieganu" University of Medicine and Pharmacy Cluj-Napoca, Romania under Internal Grant No. 4945/7/08.03.2016.

\section{CONFLICTS OF INTEREST}

The authors report no conflicts of interest.

\section{REFERENCES}

1. Van Cutsem E, Cervantes A, Nordlinger B, Arnold D, and ESMO Guidelines Working Group. Metastatic colorectal cancer: ESMO Clinical Practice Guidelines for diagnosis, treatment and follow-up. Ann Oncol. 2014; 25:iii1-9.

2. Labianca R, Nordlinger B, Beretta GD, Mosconi S, Mandalà M, Cervantes A, Arnold D, and ESMO Guidelines Working Group. Early colon cancer: ESMO Clinical Practice Guidelines for diagnosis, treatment and follow-up. Ann Oncol. 2013; 24:vi64-72.

3. Tappenden P, Chilcott J, Eggington S, Patnick J, Sakai H, Karnon J. Option appraisal of population-based colorectal cancer screening programmes in England. Gut. 2007; 56:677-684.
4. Bunger S, Zimmermann M, Habermann JK. Diversity of assessing circulating tumor cells (CTCs) emphasizes need for standardization: a CTC Guide to design and report trials. Cancer Metastasis Rev. 2015; 34:527-545.

5. Riihimaki M, Hemminki A, Sundquist J, Hemminki K. Patterns of metastasis in colon and rectal cancer. Sci Rep. 2016; 6:29765.

6. Huang MY, Tsai HL, Huang JJ, Wang JY. Clinical Implications and Future Perspectives of Circulating Tumor Cells and Biomarkers in Clinical Outcomes of Colorectal Cancer. Transl Oncol. 2016; 9:340-347.

7. Lech G, Slotwinski R, Slodkowski M, Krasnodebski IW. Colorectal cancer tumour markers and biomarkers: Recent therapeutic advances. World J Gastroenterol. 2016; 22:1745-1755.

8. Kamiyama H, Noda H, Konishi F, Rikiyama T. Molecular biomarkers for the detection of metastatic colorectal cancer cells. World J Gastroenterol. 2014; 20:8928-8938.

9. Onstenk W, Sieuwerts AM, Mostert B, Lalmahomed Z, Bolt-de Vries JB, van Galen A, Smid M, Kraan J, Van M, de Weerd V, Ramírez-Moreno R, Biermann K, Verhoef C, et al. Molecular characteristics of circulating tumor cells resemble the liver metastasis more closely than the primary tumor in metastatic colorectal cancer. Oncotarget. 2016; 7:59058-69. https://doi. org/10.18632/oncotarget.10175.

10. Pantel K, Alix-Panabieres C, Riethdorf S. Cancer micrometastases. Nat Rev Clin Oncol. 2009; 6:339-351.

11. Lianidou ES, Strati A, Markou A. Circulating tumor cells as promising novel biomarkers in solid cancers. Crit Rev Clin Lab Sci. 2014; 51:160-171.

12. Lowes LE, Hedley BD, Keeney M, Allan AL. Adaptation of semiautomated circulating tumor cell (CTC) assays for clinical and preclinical research applications. J Vis Exp. 2014; 84:e51248.

13. Lallo A, Schenk MW, Frese KK, Blackhall F, Dive C. Circulating tumor cells and CDX models as a tool for preclinical drug development. Transl Lung Cancer Res. 2017; 6:397-408.

14. Kin C, Kidess E, Poultsides GA, Visser BC, Jeffrey SS. Colorectal cancer diagnostics: biomarkers, cell-free DNA, circulating tumor cells and defining heterogeneous populations by single-cell analysis. Expert Rev Mol Diagn. 2013; 13:581-599.

15. Batth IS, Mitra A, Manier S, Ghobrial IM, Menter D, Kopetz S, Li S. Circulating tumor markers: harmonizing the yin and yang of CTCs and ctDNA for precision medicine. Ann Oncol. 2017; 28:468-477.

16. Allen JE, El-Deiry WS. Circulating Tumor Cells and Colorectal Cancer. Curr Colorectal Cancer Rep. 2010; 6:212-220.

17. Blogowski W, Bodnarczuk T, Starzynska T. Concise Review: Pancreatic Cancer and Bone Marrow-Derived Stem Cells. Stem Cells Transl Med. 2016; 5:938-945.

18. Błogowski W, Zuba-Surma E, Sałata D, Budkowska M, Dołęgowska B, Starzyńska T. Peripheral trafficking of 
bone-marrow-derived stem cells in patients with different types of gastric neoplasms. OncoImmunology. 2015; 5:e1099798.

19. Starzynska T, Dabkowski K, Blogowski W, Zuba-Surma E, Budkowska M, Salata D, Dołęgowska B, Marlicz W, Lubikowski J, Ratajczak MZ. An intensified systemic trafficking of bone marrow-derived stem/progenitor cells in patients with pancreatic cancer. J Cell Mol Med. 2013; 17:792-799.

20. Harouaka R, Kang Z, Zheng SY, Cao L. Circulating tumor cells: advances in isolation and analysis, and challenges for clinical applications. Pharmacol Ther. 2014; 141:209-221.

21. Lu Y, Yu T, Liang H, Wang J, Xie J, Shao J, Gao Y, Yu S, Chen S, Wang L, Jia L. Nitric oxide inhibits heteroadhesion of cancer cells to endothelial cells: restraining circulating tumor cells from initiating metastatic cascade. Sci Rep. 2014; 4:4344.

22. Ahn JY, Min HY, Jeong JH, Byun Y, Lee HY. A preclinical murine model for the detection of circulating human tumor cells. Anticancer Res. 2013; 33:4751-4756.

23. Massague J, Obenauf AC. Metastatic colonization by circulating tumour cells. Nature. 2016; 529:298-306.

24. Marchio S, Soster M, Cardaci S, Muratore A, Bartolini A, Barone V, Ribero D, Monti M, Bovino P, Sun J, Giavazzi $\mathrm{R}$, Asioli S, Cassoni P, et al. A complex of alpha6 integrin and E-cadherin drives liver metastasis of colorectal cancer cells through hepatic angiopoietin-like 6. EMBO Mol Med. 2012; 4:1156-1175.

25. Rahbari NN, Bork U, Kircher A, Nimitz T, Schölch S, Kahlert C, Schmidt T, Steinert G, Ulrich AB, Reissfelder C, Büchler MW, Koch M, Weitz J. Compartmental differences of circulating tumor cells in colorectal cancer. Ann Surg Oncol. 2012; 19:2195-2202.

26. Quail DF, Joyce JA. Microenvironmental regulation of tumor progression and metastasis. Nat Med. 2013; 19:1423-1437.

27. Steinert G, Scholch S, Niemietz T, Iwata N, Garcia SA, Behrens B, Voigt A, Kloor M, Benner A, Bork U, Rahbari NN, Büchler MW, Stoecklein NH, et al. Immune escape and survival mechanisms in circulating tumor cells of colorectal cancer. Cancer Res. 2014; 74:1694-1704.

28. Kidess-Sigal E, Liu HE, Triboulet MM, Che J, Ramani VC, Visser BC, Poultsides GA, Longacre TA, Marziali A, Vysotskaia V, Wiggin M, Heirich K, Hanft V, et al. Enumeration and targeted analysis of KRAS, BRAF and PIK3CA mutations in CTCs captured by a label-free platform: Comparison to ctDNA and tissue in metastatic colorectal cancer. Oncotarget. 2016; 7:85349-64. https:// doi.org/10.18632/oncotarget.13350.

29. Séronie-Vivien S. [Circulating tumor cells: a new challenge for laboratory medicine]. [Article in French]. Ann Biol Clin (Paris). 2014; 72:153-77.

30. Cools-Lartigue J, Spicer J, McDonald B, Gowing S, Chow S, Giannias B, Bourdeau F, Kubes P, Ferri L. Neutrophil extracellular traps sequester circulating tumor cells and promote metastasis. J Clin Invest. 2013; 123:3446-3458. https://doi.org/10.1172/JCI67484.

31. Hamilton G, Rath B. Circulating tumor cell interactions with macrophages: implications for biology and treatment. Transl Lung Cancer Res. 2017; 6:418-430.

32. Hamilton G, Rath B, Klameth L, Hochmair MJ. Small cell lung cancer: Recruitment of macrophages by circulating tumor cells. OncoImmunology. 2015; 5:e1093277.

33. Santos MF, Mannam VK, Craft BS, Puneky LV, Sheehan NT, Lewis RE, Cruse JM. Comparative analysis of innate immune system function in metastatic breast, colorectal, and prostate cancer patients with circulating tumor cells. Exp Mol Pathol. 2014; 96:367-374.

34. Plaks V, Koopman CD, Werb Z. Cancer. Circulating tumor cells. Science. 2013; 341:1186-1188.

35. Chen Q, Tang Q, Chen Y, Wang X. [Application and prospect of circulating tumor cells detection in colorectal cancer]. [Article in Chinese]. Zhonghua Wei Chang Wai Ke Za Zhi. 2016; 19:717-20.

36. Krell J, Stebbing J. Circulating tumour cells as biomarkers in early breast cancer. Lancet Oncol. 2012; 13:653-654.

37. Souza E Silva V, Chinen LT, Abdallah EA, Damascena A, Paludo J, Chojniak R, Dettino AL, de Mello CA, Alves VS, Fanelli MF. Early detection of poor outcome in patients with metastatic colorectal cancer: tumor kinetics evaluated by circulating tumor cells. OncoTargets Ther. 2016; 9:7503-7513.

38. Tan CR, Zhou L, El-Deiry WS. Circulating Tumor Cells Versus Circulating Tumor DNA in Colorectal Cancer: Pros and Cons. Curr Colorectal Cancer Rep. 2016; 12:151-161.

39. Welinder C, Jansson B, Lindell G, Wenner J. Cytokeratin 20 improves the detection of circulating tumor cells in patients with colorectal cancer. Cancer Lett. 2015; 358:43-46.

40. Nicolazzo C, Massimi I, Lotti LV, Vespa S, Raimondi C, Pulcinelli FM, Gradilone A, Gazzaniga P. Impact of chronic exposure to bevacizumab on EpCAM-based detection of circulating tumor cells. Chin J Cancer Res. 2015; 27:491-496.

41. Gorges TM, Stein A, Quidde J, Hauch S, Röck K, Riethdorf S, Joosse SA, Pantel K. Improved Detection of Circulating Tumor Cells in Metastatic Colorectal Cancer by the Combination of the CellSearch ${ }^{\circledR}$ System and the AdnaTest ${ }^{\circledR}$. PLoS One. 2016; 11:e0155126.

42. King JD, Casavant BP, Lang JM. Rapid translation of circulating tumor cell biomarkers into clinical practice: technology development, clinical needs and regulatory requirements. Lab Chip. 2014; 14:24-31.

43. Chen JY, Tsai WS, Shao HJ, Wu JC, Lai JM, Lu SH, Hung TF, Yang CT, Wu LC, Chen JS, Lee WH, Chang YC. Sensitive and Specific Biomimetic Lipid Coated Microfluidics to Isolate Viable Circulating Tumor Cells and Microemboli for Cancer Detection. PloS One. 2016; 11:e0149633.

44. Gogoi P, Sepehri S, Zhou Y, Gorin MA, Paolillo C, Capoluongo E, Gleason K, Payne A, Boniface B, 
Cristofanilli M, Morgan TM, Fortina P, Pienta KJ, et al. Development of an Automated and Sensitive Microfluidic Device for Capturing and Characterizing Circulating Tumor Cells (CTCs) from Clinical Blood Samples. PloS One. 2016; 11:e0147400.

45. Huang YY, Chen P, Wu CH, Hoshino K, Sokolov K, Lane N, Liu H, Huebschman M, Frenkel E, Zhang JX. Screening and Molecular Analysis of Single Circulating Tumor Cells Using Micromagnet Array. Sci Rep. 2015; 5:16047.

46. Chen P, Huang YY, Bhave G, Hoshino K, Zhang X. Inkjet-Print Micromagnet Array on Glass Slides for Immunomagnetic Enrichment of Circulating Tumor Cells. Ann Biomed Eng. 2016; 44:1710-1720.

47. Han SI, Han KH. Electrical Detection Method for Circulating Tumor Cells Using Graphene Nanoplates. Anal Chem. 2015; 87:10585-10592.

48. Lu Y, Liang H, Yu T, Xie J, Chen S, Dong H, Sinko PJ, Lian S, Xu J, Wang J, Yu S, Shao J, Yuan B, et al. Isolation and characterization of living circulating tumor cells in patients by immunomagnetic negative enrichment coupled with flow cytometry. Cancer. 2015; 121:3036-3045.

49. Kaifi JT, Kunkel M, Das A, Harouaka RA, Dicker DT, Li G, Zhu J, Clawson GA, Yang Z, Reed MF, Gusani NJ, Kimchi ET, Staveley-O'Carroll KF, et al. Circulating tumor cell isolation during resection of colorectal cancer lung and liver metastases: a prospective trial with different detection techniques. Cancer Biol Ther. 2015; 16:699-708.

50. Wan Y, Winter M, Delalat B, Hardingham JE, Grover PK, Wrin J, Voelcker NH, Price TJ, Thierry B. Nanostructured polystyrene well plates allow unbiased high-throughput characterization of circulating tumor cells. ACS Appl Mater Interfaces. 2014; 6:20828-20836.

51. Matsusaka S, Kozuka M, Takagi H, Ito H, Minowa S, Hirai M, Hatake K. A novel detection strategy for living circulating tumor cells using 5-aminolevulinic acid. Cancer Lett. 2014; 355:113-120.

52. Vaiopoulos AG, Kostakis ID, Gkioka E, Athanasoula K, Pikoulis E, Papalambros A, Christopoulos P, Gogas H, Kouraklis G, Koutsilieris M. Detection of circulating tumor cells in colorectal and gastric cancer using a multiplex PCR assay. Anticancer Res. 2014; 34:3083-3092.

53. Ranc V, Srovnal J, Kvitek L, Hajduch M. Discrimination of circulating tumor cells of breast cancer and colorectal cancer from normal human mononuclear cells using Raman spectroscopy. Analyst. 2013; 138:5983-5988.

54. He R, Zhao L, Liu Y, Zhang N, Cheng B, He Z, Cai B, Li S, Liu W, Guo S, Chen Y, Xiong B, Zhao XZ. Biocompatible $\mathrm{TiO} 2$ nanoparticle-based cell immunoassay for circulating tumor cells capture and identification from cancer patients. Biomed Microdevices. 2013; 15:617-626.

55. Fabbri F, Carloni S, Zoli W, Ulivi P, Gallerani G, Fici P, Chiadini E, Passardi A, Frassineti GL, Ragazzini A, Amadori D. Detection and recovery of circulating colon cancer cells using a dielectrophoresis-based device:
KRAS mutation status in pure CTCs. Cancer Lett. 2013; 335:225-231.

56. Zhang H, Fu X, Hu J, Zhu Z. Microfluidic bead-based multienzyme-nanoparticle amplification for detection of circulating tumor cells in the blood using quantum dots labels. Anal Chim Acta. 2013; 779:64-71.

57. Sun W, Jia C, Huang T, Sheng W, Li G, Zhang H, Jing F, Jin Q, Zhao J, Li G, Zhang Z. High-performance size-based microdevice for the detection of circulating tumor cells from peripheral blood in rectal cancer patients. PloS One. 2013; 8:e75865.

58. Gazouli M, Lyberopoulou A, Pericleous P, Rizos S, Aravantinos G, Nikiteas N, Anagnou NP, Efstathopoulos EP. Development of a quantum-dot-labelled magnetic immunoassay method for circulating colorectal cancer cell detection. World J Gastroenterol. 2012; 18:4419-4426.

59. Zhang N, Deng Y, Tai Q, Cheng B, Zhao L, Shen Q, Hong L, Liu W, Guo S, Liu K, Tseng HR, Xiong B, Zhao XZ. Electrospun $\mathrm{TiO} 2$ nanofiber-based cell capture assay for detecting circulating tumor cells from colorectal and gastric cancer patients. Adv Mater. 2012; 24:2756-2760.

60. Desitter I, Guerrouahen BS, Benali-Furet N, Wechsler J, Janne PA, Kuang Y, Yanagita M, Wang L, Berkowitz JA, Distel RJ, Cayre YE. A new device for rapid isolation by size and characterization of rare circulating tumor cells. Anticancer Res. 2011; 31:427-441.

61. Deneve E, Riethdorf S, Ramos J, Nocca D, Coffy A, Daures JP, Maudelonde T, Fabre JM, Pantel K, Alix-Panabières C. Capture of viable circulating tumor cells in the liver of colorectal cancer patients. Clin Chem. 2013; 59:1384-1392.

62. Barbazan J, Vieito M, Abalo A, Alonso-Alconada L, Muinelo-Romay L, Alonso-Nocelo M, León L, Candamio S, Gallardo E, Anido U, Doll A, de los Ángeles Casares M, Gómez-Tato A, et al. A logistic model for the detection of circulating tumour cells in human metastatic colorectal cancer. J Cell Mol Med. 2012; 16:2342-2349.

63. Dharmasiri U, Njoroge SK, Witek MA, Adebiyi MG, Kamande JW, Hupert ML, Barany F, Soper SA. High-throughput selection, enumeration, electrokinetic manipulation, and molecular profiling of low-abundance circulating tumor cells using a microfluidic system. Anal Chem. 2011; 83:2301-2309.

64. Jia S, Zhang R, Li Z, Li J. Clinical and biological significance of circulating tumor cells, circulating tumor DNA, and exosomes as biomarkers in colorectal cancer. Oncotarget. 2017; 8:55632-45. https://doi.org/10.18632/ oncotarget.17184.

65. Wang JY, Wu CH, Lu CY, Hsieh JS, Wu DC, Huang SY, Lin SR. Molecular detection of circulating tumor cells in the peripheral blood of patients with colorectal cancer using RT-PCR: significance of the prediction of postoperative metastasis. World J Surg. 2006; 30:1007-1013.

66. Steinert G, Scholch S, Koch M, Weitz J. Biology and significance of circulating and disseminated tumour cells in colorectal cancer. Langenbecks Arch Surg. 2012; 397:535-542. 
67. Hardingham JE, Grover P, Winter M, Hewett PJ, Price TJ, Thierry B. Detection and Clinical Significance of Circulating Tumor Cells in Colorectal Cancer--20 Years of Progress. Mol Med. 2015; 21:S25-31.

68. Huang X, Gao P, Song Y, Sun J, Chen X, Zhao J, Xu $\mathrm{H}$, Wang Z. Meta-analysis of the prognostic value of circulating tumor cells detected with the CellSearch System in colorectal cancer. BMC Cancer. 2015; 15:202.

69. Mitra A, Mishra L, Li S. EMT, CTCs and CSCs in tumor relapse and drug-resistance. Oncotarget. 2015; 6:10697-711. https://doi.org/10.18632/oncotarget.4037.

70. Ning Y, Zhang W, Hanna DL, Yang D, Okazaki S, Berger MD, Miyamoto Y, Suenaga M, Schirripa M, El-Khoueiry A, Lenz H. Clinical relevance of EMT and stem-like gene expression in circulating tumor cells of metastatic colorectal cancer patients. Pharmacogenomics J. 2018; 18:29-34.

71. Mostert B, Sieuwerts AM, Bolt-de Vries J, Kraan J, Lalmahomed Z, van Galen A, van der Spoel P, de Weerd V, Ramírez-Moreno R, Smid M, Verhoef C, IJzermans JN, Gratama JW, et al. mRNA expression profiles in circulating tumor cells of metastatic colorectal cancer patients. Mol Oncol. 2015; 9:920-932.

72. Fang C, Fan C, Wang C, Huang Q, Meng W, Yu Y, Yang L, Peng Z, Hu J, Li Y, Mo X, Zhou Z. CD133+CD54+CD44+ circulating tumor cells as a biomarker of treatment selection and liver metastasis in patients with colorectal cancer. Oncotarget. 2016; 7:77389-403. https://doi. org/10.18632/oncotarget.12675.

73. Cohen SJ, Punt CJ, Iannotti N, Saidman BH, Sabbath KD, Gabrail NY, Picus J, Morse M, Mitchell E, Miller MC, Doyle GV, Tissing H, Terstappen LW, et al. Relationship of circulating tumor cells to tumor response, progressionfree survival, and overall survival in patients with metastatic colorectal cancer. J Clin Oncol. 2008; 26:3213-3221.

74. Tol J, Koopman M, Miller MC, Tibbe A, Cats A, Creemers GJ, Vos AH, Nagtegaal ID, Terstappen LW, Punt CJ. Circulating tumour cells early predict progression-free and overall survival in advanced colorectal cancer patients treated with chemotherapy and targeted agents. Ann Oncol. 2010; 21:1006-1012.

75. Matsusaka S, Suenaga M, Mishima Y, Kuniyoshi R, Takagi K, Terui Y, Mizunuma N, Hatake K. Circulating tumor cells as a surrogate marker for determining response to chemotherapy in Japanese patients with metastatic colorectal cancer. Cancer Sci. 2011; 102:1188-1192.

76. Sastre J, Maestro ML, Gomez-Espana A, Rivera F, Valladares M, Massuti B, Benavides M, Gallén M, Marcuello E, Abad A, Arrivi A, Fernández-Martos C, González E, et al. Circulating tumor cell count is a prognostic factor in metastatic colorectal cancer patients receiving first-line chemotherapy plus bevacizumab: a Spanish Cooperative Group for the Treatment of Digestive Tumors study. Oncologist. 2012; 17:947-955.

77. de Albuquerque A, Kubisch I, Stolzel U, Ernst D, BoeseLandgraf J, Breier G, Stamminger G, Fersis N, Kaul S.
Prognostic and predictive value of circulating tumor cell analysis in colorectal cancer patients. J Transl Med. 2012; 10:222.

78. Barbazan J, Muinelo-Romay L, Vieito M, Candamio S, Diaz-Lopez A, Cano A, Gómez-Tato A, Casares de Cal Mde L, Abal M, López-López R. A multimarker panel for circulating tumor cells detection predicts patient outcome and therapy response in metastatic colorectal cancer. Int J Cancer. 2014; 135:2633-2643.

79. Gazzaniga P, Raimondi C, Nicolazzo C, Carletti R, di Gioia $\mathrm{C}$, Gradilone A, Cortesi E. The rationale for liquid biopsy in colorectal cancer: a focus on circulating tumor cells. Expert Rev Mol Diagn. 2015; 15:925-932.

80. Ignatiadis M, Lee M, Jeffrey SS. Circulating Tumor Cells and Circulating Tumor DNA: Challenges and Opportunities on the Path to Clinical Utility. Clin Cancer Res. 2015; 21:4786-4800.

81. Diaz LA Jr, Bardelli A. Liquid biopsies: genotyping circulating tumor DNA. J Clin Oncol. 2014; 32:579-586.

82. Misale S, Yaeger R, Hobor S, Scala E, Janakiraman M, Liska D, Valtorta E, Schiavo R, Buscarino M, Siravegna G, Bencardino K, Cercek A, Chen CT, et al. Emergence of KRAS mutations and acquired resistance to anti-EGFR therapy in colorectal cancer. Nature. 2012; 486:532-536.

83. Van Emburgh BO, Arena S, Siravegna G, Lazzari L, Crisafulli G, Corti G, Mussolin B, Baldi F, Buscarino M, Bartolini A, Valtorta E, Vidal J, Bellosillo B, et al. Acquired RAS or EGFR mutations and duration of response to EGFR blockade in colorectal cancer. Nat Commun. 2016; 7:13665.

84. Oddo D, Sennott EM, Barault L, Valtorta E, Arena S, Cassingena A, Filiciotto G, Marzolla G, Elez E, van Geel RM, Bartolini A, Crisafulli G, Boscaro V, et al. Molecular Landscape of Acquired Resistance to Targeted Therapy Combinations in BRAF-Mutant Colorectal Cancer. Cancer Res. 2016; 76:4504-4515.

85. Tie J, Wang Y, Tomasetti C, Li L, Springer S, Kinde I, Silliman N, Tacey M, Wong HL, Christie M, Kosmider S, Skinner I, Wong R, et al. Circulating tumor DNA analysis detects minimal residual disease and predicts recurrence in patients with stage II colon cancer. Sci Transl Med. 2016; 8:346ra92.

86. Denis JA, Patroni A, Guillerm E, Pepin D, Benali-Furet N, Wechsler J, Manceau G, Bernard M, Coulet F, Larsen AK, Karoui M, Lacorte JM. Droplet digital PCR of circulating tumor cells from colorectal cancer patients can predict KRAS mutations before surgery. Mol Oncol. 2016; 10:1221-1231.

87. Gutierrez C, Rodriguez J, Patino-Garcia A, Garcia-Foncillas J, Salgado J. KRAS mutational status analysis of peripheral blood isolated circulating tumor cells in metastatic colorectal patients. Oncol Lett. 2013; 6:1343-1345.

88. Mostert B, Jiang Y, Sieuwerts AM, Wang H, Bolt-de Vries J, Biermann K, Kraan J, Lalmahomed Z, van Galen A, de Weerd V, van der Spoel P, Ramírez-Moreno R, Verhoef $\mathrm{C}$, et al. KRAS and BRAF mutation status in circulating 
colorectal tumor cells and their correlation with primary and metastatic tumor tissue. Int J Cancer. 2013; 133:130-141.

89. Huang MM, Leong SM, Chua HW, Tucker S, Cheong WC, Chiu L, Li MH, Koay ES. Highly sensitive KRAS mutation detection from formalin-fixed paraffin-embedded biopsies and circulating tumour cells using wild-type blocking polymerase chain reaction and Sanger sequencing. Mol Diagn Ther. 2014; 18:459-468.

90. Satelli A, Batth IS, Brownlee Z, Rojas C, Meng QH, Kopetz S, Li S. Potential role of nuclear PD-L1 expression in cell-surface vimentin positive circulating tumor cells as a prognostic marker in cancer patients. Sci Rep. 2016; 6:28910.

91. Sugimachi K, Yokobori T, Iinuma H, Ueda M, Ueo H, Shinden Y, Eguchi H, Sudo T, Suzuki A, Maehara Y, Mori M, Mimori K. Aberrant expression of plastin-3 via copy number gain induces the epithelial-mesenchymal transition in circulating colorectal cancer cells. Ann Surg Oncol. 2014; $21: 3680-3690$. 